\title{
スケーリング後の歯面研磨装置の応用について
}

\author{
増 田晴美荒井法行清水伸 \\ 江橋真一. 伊藤公一村井正大 \\ 日本大学歯学部歯周病学教室 \\ (主任 : 村井正大教授) \\ (昭和 62 年 6 月 16 日受付)
}

\section{In Vitro Study of the Effectiveness of the Air-Powder Abrasive System to the Scaled Root Surfaces}

\author{
Harumi MASUDA, Noriyuki ARAI, Shin SHIMIZU, \\ Shin-ichi EBASHI, Koichi ITO and Seidai MURAI
}

Department of Periodontology, Nihon University, School of Dentistry

(Chief : Prof. Seidai MURAI)

The purpose of this study was to investigate the effectiveness of the air-powder abrasive system (Quick-jet@, YOSHIDA Co.) to the scaled root surfaces in vitro. Scaled surfaces were treated with the Quick-jet with different time (for 3, 5, 10 and 20 seconds) and angle $\left(60^{\circ}\right.$ and $\left.90^{\circ}\right)$. After treatment, the characteristics of surfaces were observed using scanning electron microscope (SEM) and the roughness was also measured.
The results of SEM observation indicated that the surfaces treated with angle of $90^{\circ}$ were more smoother than those with angle of $60^{\circ}$. When this system used more than 10 seconds, the rugged characteristics of the surfaces were disappeared and also the dentin like structure were observed. There was the same tendency in the roughness measurement.

These results suggested that this system seem to represent the effectiveness similar to root planing.

Key words : Scaling, Air-powder abrasive system, Scanning electron microscopic observation, Roughness of root surfaces

要旨 : Air-powder abrasive system を，スケーリング後の歯面研磨に応用した場合の効果について in vitro で検 討を行った。スケーリング後の歯面に，3秒， 5 秒， 10 秒， 20 秒間，チップの角度を 60 度，90度と変え噴射した。 その影響を SEM にて観察し，あわせて表面粗さを測定した。その結果，SEM 観察では，噴射角度については, 60 度 噴射処理面よりも 90 度噴射処理面の方が表面の凹凸が小さく, 噴射時間については, 10 秒以上の噴射では, 表面の凹 凸が不鮮明になり，象牙細管様構造も認められた。表面粗さは，時間が長くなるにしたがい小さくなり，60度噴射処 理よりも 90 度噴射処理面の方が小さかった。本実験の結果, 使用条件を考慮すれば, 本装置は, スケーリング後のル ートプレーニング的な役割を果たすことが示唆された。

索引用語 : スケーリング, 歯面研磨装置, 電子顕微鏡観察, 歯根面粗さ 


\section{緒言}

歯周治療において，歯面に付着するプラーク，歯石な どを除去し，さらに，根面を滑沢にすることは，治療の 成否を決定する重要な因子であるといわれている。歯石 除去は従来から超音波スケーラー, 手用スケーラーなど が頻用されているが，その歯面は粗造であるため，主に ペーストを歯面に塗布しティースブラシ，ラバーカップ を用いて研磨する方法がとられている。しかし，これら の操作には，時間がかかり，また歯面全体におよぶ細部 までの研磨が難しい。

最近, 外来性沈着物の除去に, 歯面研磨装置として重 炭酸ナトリウムなどの微細粉末と水をジェット噴流で歯 面に噴射し，着色物を除去するという air-powder abrasive system を応用する装置が開発され，数種の装置が 市販されている。これらの装置は, プラークや外来性沈 着物の除去においてラバーカップ, ペースト研磨などに くらべ短時間の操作で, 高い除去効果を得られることが 報告されている1 7)。しかしながら，それらの報告はプラ 一クや外来性沈着物の除去に使用したものが主である。

今回，著者らは，スケーリング後この歯面研磨装置を 応用した場合, ルートプレーニング面あるいはペースト による研磨面のような面が得られるかどらか歯面研磨装 置の噴射する角度, および噴射時間により検討し, 興味 ある知見を得たので報告する。

\section{材料および方法}

\section{1. 材 料 \\ 1) 被験歯}

日本大学歯科病院来院患者の歯周疾患罹患歯で要抜去 と診断された上效中切歯を, 歯根面に損傷をなるべく与 えないよう抜去したのち, 流水下でプラークなどの付着 物を除去し, 滅菌精製水中に保存したものを被験歯とし た。

\section{2) 使用器具}

歯面研磨装置 (クイックジェット®，ヨシダ社製）を使 用空気圧 $2.0 \sim 2.2 \mathrm{~kg} / \mathrm{cm}^{2}$, 使用水圧 $2.0 \mathrm{~kg} / \mathrm{cm}^{2}$, パウ ダー吐出量 $4 \sim 5 \mathrm{~g} / \mathrm{min}$ (空気量最大時) で使用した。パ ウダーは, 粒子の一辺が $40 \mu \mathrm{m}$ 前後の炭酸水素ナトリ ウムの粉末を用いた。

\section{2. 方 法}

1) 試料の調整

被験歯の根面を，超音波スケーラー $(40 \mathrm{~K}$ リッタート ロン E, tip 10, sickle type, powder 4, Ritter 社製) で 20 回擦過し，肉眼で認められる歯石を全て除去したもの をスケーリング面とした。

これらのスケーリング面に対し，根面の右側半分を鉛 板で覆ったのち, 左側には, 歯面研磨装置のノズルを歯 冠方向より 60 度の角度にし, $5 \mathrm{~mm}$ の距離から 3 秒, 5 秒， 10 秒， 20 秒間噴射した。さらに，右側に対しては， 左側を鉛板にて覆ったのち，ノズルを歯冠方向より 90 度の角度で，左側と同様に $5 \mathrm{~mm}$ の距離から 3 秒， 5 秒， 10 秒, 20 秒間噴射して観察試料とした。

2) SEM の試料

各試片をVibroclean 200 (米国 MDT 社製) にて 20 分間洗浄後, $0.1 \mathrm{M}$ カコジル酸ナトリウム緩衝 液 $(\mathrm{pH}$ 7.4) で $1 \%$ に調整されたグルタルアルデヒド溶液に て 2 時間浸漬固定を行ない, 同緩衝液で水洗, エタノー ルにて脱水後, 䣷酸イソアミルに置換し, 臨界点乾燥 (HCP-1, 日立社製) 後, クイックコーター (SC-701 型, サンコー電子社製) を用いて金蒸着を行ない $\mathrm{SEM}$ (HHS-2 R 日立社製) を用いて観察した。観察部位は, 根面を歯冠寄り, 中央, 根尖寄りの 3 部位に分け, この うち歯冠寄り, 中央部の 2 部位の観察を行なった。

3）噴射による粗さの測定

歯面研磨装置使用前, 3 秒, 5 秒, 10 秒, 20 秒, 噴射時 について, 試料を超音波洗浄後, 表面粗さ形状解析シス テム Surfcom 200 (東京技研社製) にて測定針の直径 5 $\mu$, 測定長さ $\pm 0.8 \mathrm{~mm}$, カットオフ值 $0.25 \mathrm{~mm}$, 測定ス ピード $0.12 \mathrm{~mm} / \mathrm{sec}$ にて測定を行なった。

測定パラメータは, 最大粗さ $\left(\mathrm{R}_{\max }\right)$ と標㔼粗さ $(\mathrm{Ra})$ とし, 各々 7 回測定し, 最大最小值を切りすて残り 5 回 にっいて平均および標準偏差を求めた。

\section{実 験 成 績}

\section{SEM 観察}

スケーリング面に対して 60 度および 90 度の角度で噴 射した処理面を図 1-14 に示した。なお, 図 1-6 は歯冠側 より歯根処理面，図 7-14 は歯根中央部処理面である。

1) 歯冠 (CEJ から根尖側約 $5 \mathrm{~mm}$ まで) より歯根 処理面

3 秒間, 60 度噴射処理面ではスケーリング時の条痕を 認め, 歯冠側から歯根側へのめくれあがりが認められ 


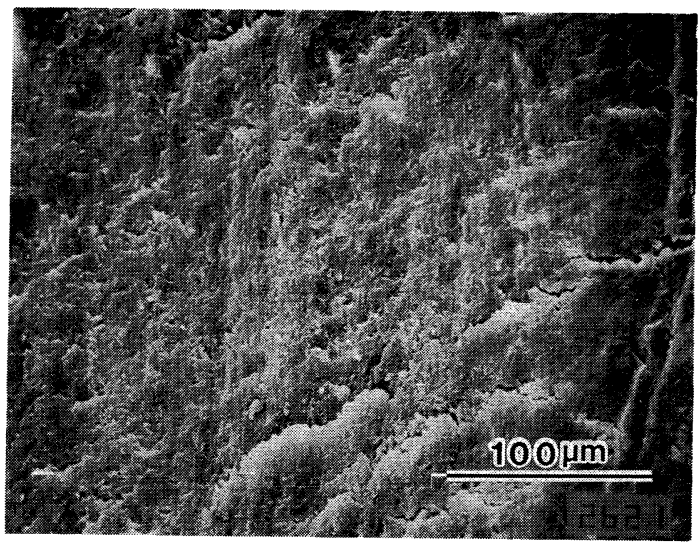

図 1 歯冠側より 3 秒間, 60 度噴射処理面 $(\times 350)$

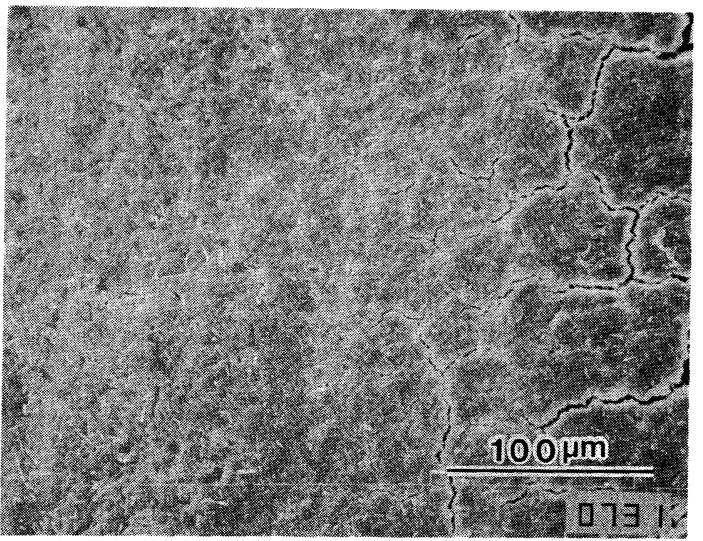

図 2 歯冠側より 3 秒間, 90 度噴射処理面 $(\times 350)$

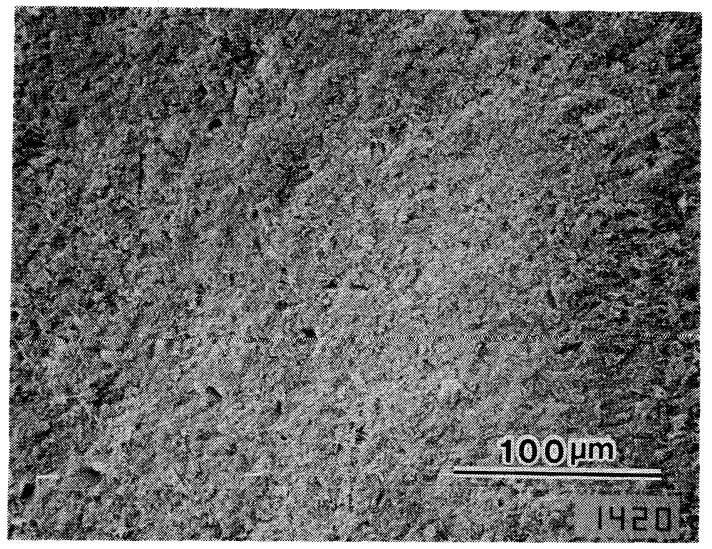

図 3 歯冠側より 5 秒間, 60 度噴射処理面 $(\times 350)$

た。90 度噴射処理面では，条痕は認められず，平滑な面 の中に象牙細管が点在している像を認めた。

5 秒間, 60 度噴射処理面では歯冠側へ向けてのめくれ あがりは認められず，全体として，表面の凹凸は小さく

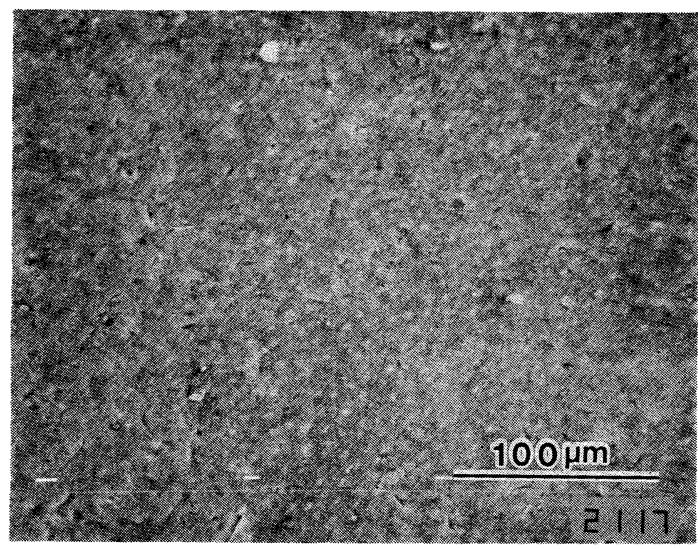

図 4 歯冠側より 5 秒間, 90 度噴射処理面 $(\times 350)$

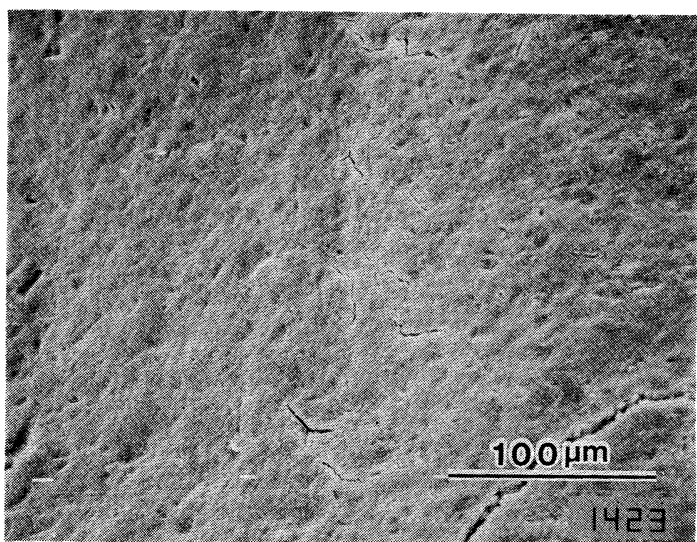

図 5 歯冠側より 10 秒間, 60 度噴射処理面 $(\times 350)$

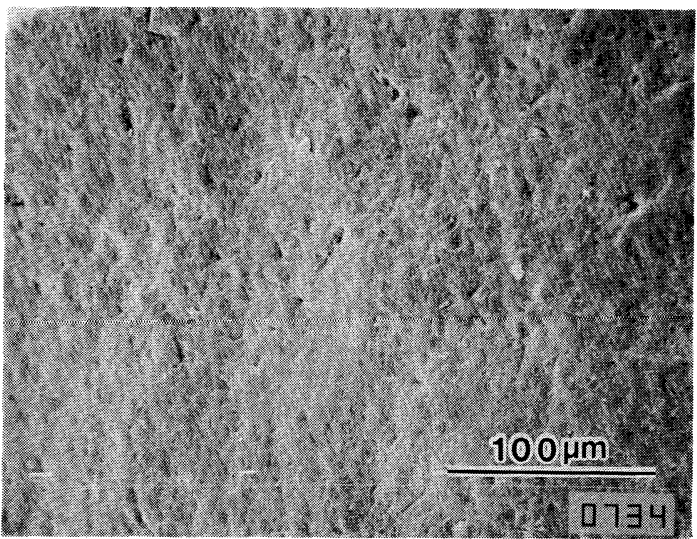

図 6 歯冠側より 10 秒間, 90 度噴射処理面 $(\times 350)$

規則的になり，平滑な像が観察された。とくに 90 度噴射 処理面は，凹凸が小さく規則的な平滑な像を呈してい た。

10 秒間，噴射のそれぞれの処理面は， 5 秒間のものと 


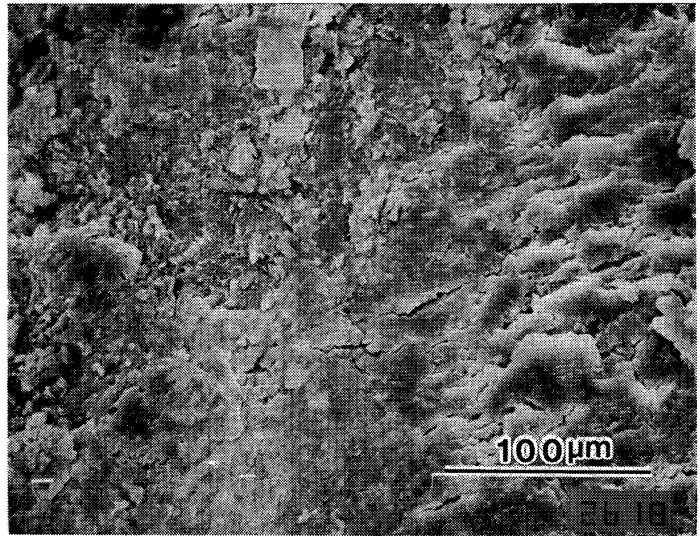

図 7 中央部 3 秒間, 60 度噴射処理面 $(\times 350)$

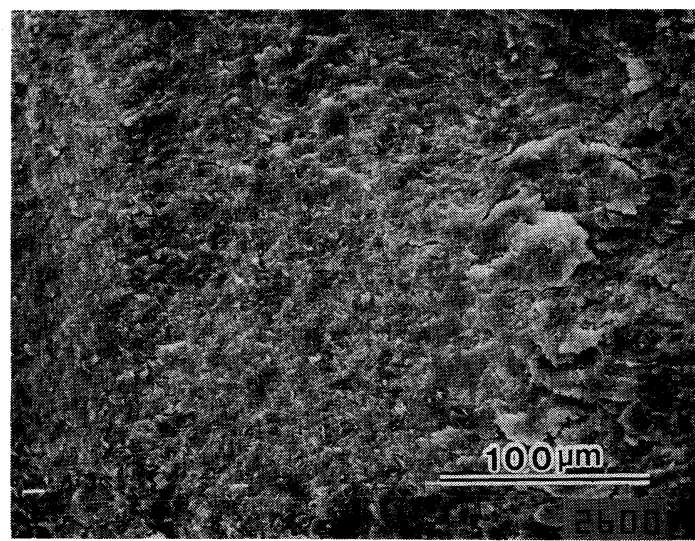

図 8 中央部 3 秒間, 90 度噴射処理面 $(\times 350)$

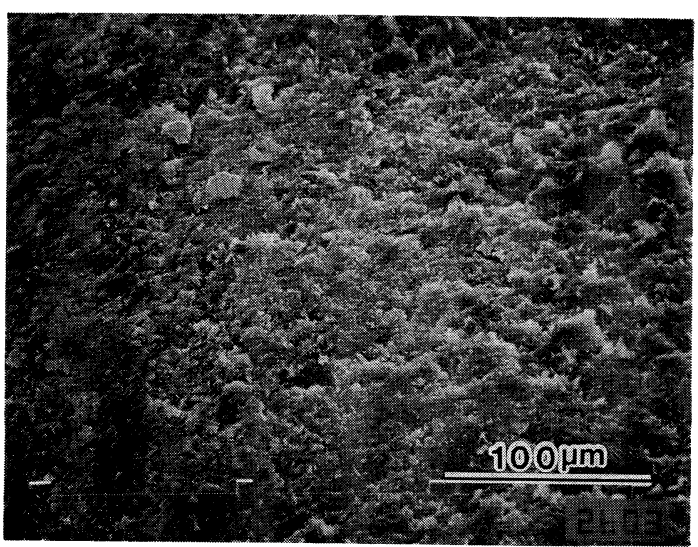

図 9 中央部 5 秒間, 60 度噴射処理面 $(\times 350)$

同様の所見を得たが，象牙細管の開口部がより鮮明に認 められた。

2) 中央部処理面

3 秒間, 60 度噴射処理面では, 噴射のためと思われる

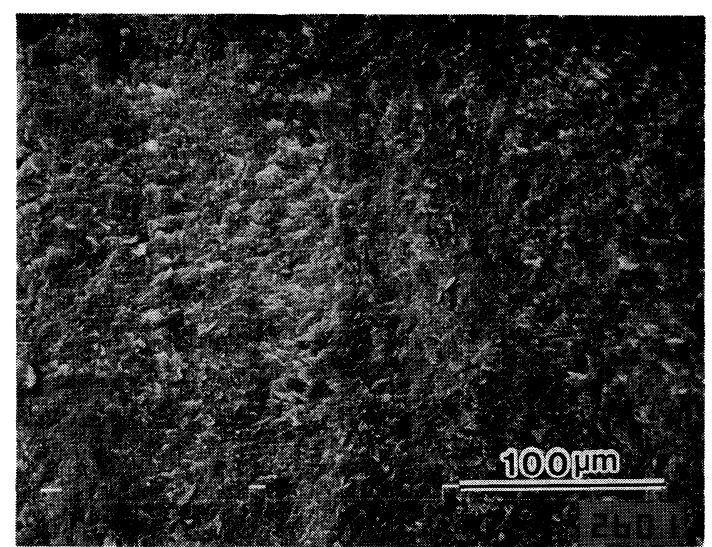

図 10 中央部 5 秒間, 90 度噴射処理面 $(\times 350)$

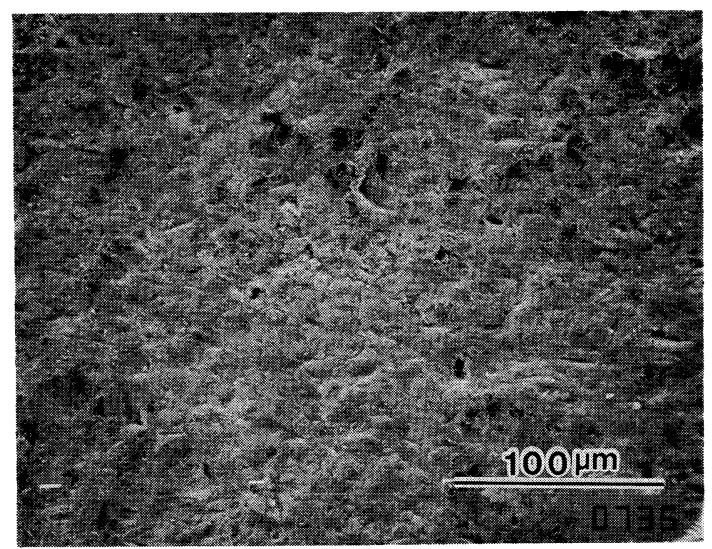

図 11 中央部 10 秒間, 60 度噴射処理面 $(\times 350)$

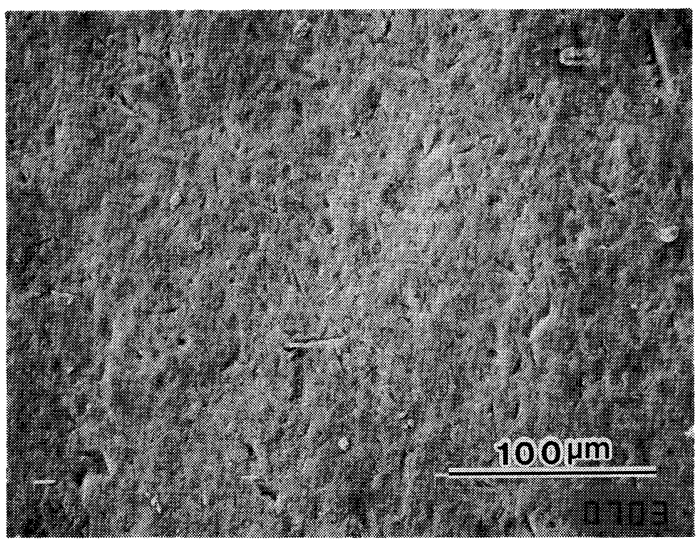

図 12 中央部 10 秒間, 90 度噴射処理面 $(\times 350)$

歯冠側から根尖側へ向けての大小さまざまなセメント質 のめくれあがりが認められた。一方, 90 度噴射処理面で は，歯冠側へ向けてのめくれあがりが少なく, 60 度噴射 処理面にくらべて表面の凹凸が小さい像が観察された。 


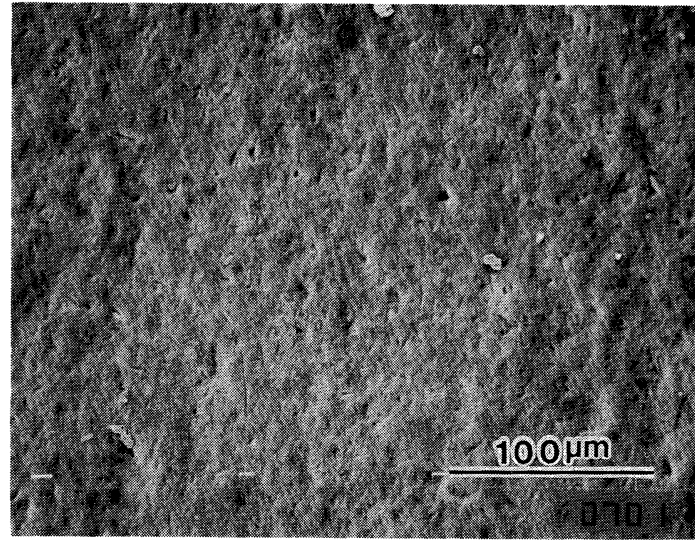

図 13 中央部 20 秒間, 60 度噴射処理面 $(\times 350)$

5 秒間， 60 度噴射処理面では，歯冠側から歯根側へ向 けてのめくれあがりが認められたが， 3 秒間噴射処理面 に比して，めくれあがりが少なく減少している像が観察 された。90度噴射処理面では, 60 度噴射処理面にくらべ て，めくれあがりはほとんど認められず，3秒間噴射処 理と同様に小さな凹凸のある像が認められた。

10 秒間, 60 度噴射処理面では, 全体としてかなり平滑 な像の中に象牙細管が観察された。とくに 90 度噴射 処 理面では，表面の小さな凹凸の像も不鮮明になり，その 凹みが浅く平滑な像を呈し，象牙細管が認められた。

20 秒間, 60 度および 90 度の噴射処理面では 10 秒噴 射処理面と同様の像を呈し, 顕著な差は認められなかっ た。

\section{2. 噴射時間による表面粗さ}

スケーリング面に対して 60 度および 90 度の角度で, 3 秒, 5 秒, 10 秒および 20 秒噴射した処理面の最大粗さ （Rmax）と，標準粗さ（Ra）の平均および標準偏差を表 1 に示した。

60 度および 90 度処理面とも， 3 秒噴射での $R_{\text {max }}$ は それぞれ $5.5 \pm 0.08 \mu \mathrm{m}, 4.2 \pm 0.10 \mu \mathrm{m}, \mathrm{Ra}$ は $0.7 \pm 0.06$ $\mu \mathrm{m}, 0.5 \pm 0.08 \mu \mathrm{m}$ であり, 20 秒噴射での $\mathrm{R}_{\max }$ はそれ ぞれ $2.8 \pm 0.05 \mu \mathrm{m}, 2.0 \pm 0.14 \mu \mathrm{m}, \mathrm{Ra}$ は $0.4 \pm 0.03 \mu \mathrm{m}$, $0.3 \pm 0.03 \mu \mathrm{m}$ と噴射時間が長くなるにしたがい $R_{\max }$, Ra ともに粗さは減少した。しかしながら, 10 秒と 20 秒 噴射処理面を比較寸ると有意な差は認められなかった。

一方，噴射角度を比較すると，3秒噴射での 60 度処理 面の $R_{\max }$ は $5.5 \pm 0.08 \mu \mathrm{m}, 90$ 度処理面では $4.2 \pm 0.10$ $\mu \mathrm{m}$ であり,また 20 秒噴射での $\mathrm{R}_{\max }$ も 60 度, 90 度処 理面それぞれ $2.8 \pm 0.05 \mu \mathrm{m}, 2.0 \pm 0.14 \mu \mathrm{m}$ と, 各時間 の処理面とも, 60 度処理面にくらべ, 90 度処理面の方が

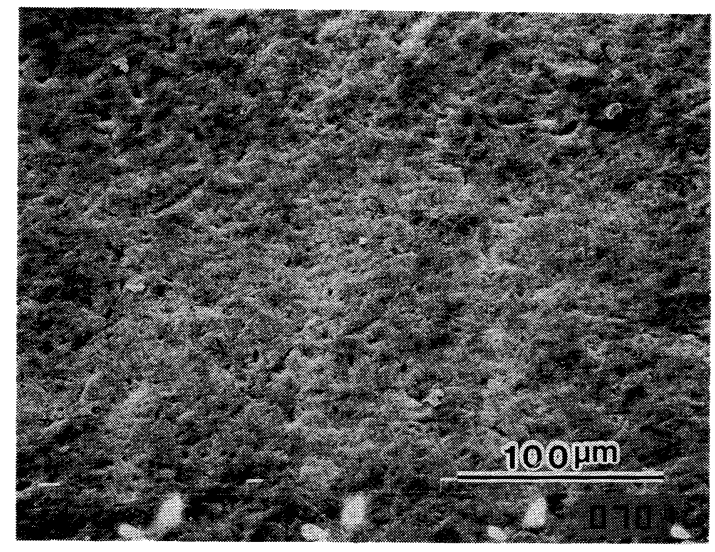

図 14 中央部 20 秒間, 90 度噴射処理面 $(\times 350)$

表 1 各噴射角度および時間による表面粗さ

\begin{tabular}{|c|c|c|c|}
\hline & 角度 & $60^{\circ}$ & $90^{\circ}$ \\
\hline \multirow{2}{*}{$3 \mathrm{sec}$} & $R \max$ & $5.5 \pm 0.08$ & $4.2 \pm 0.10$ \\
\hline & $\mathrm{Ra}$ & $0.7 \pm 0.06$ & $0.5 \pm 0.08$ \\
\hline \multirow{2}{*}{$5 \mathrm{sec}$} & $R \max$ & $4.6 \pm 0.14$ & $3.1 \pm 0.13$ \\
\hline & $\mathrm{Ra}$ & $0.6 \pm 0.02$ & $0.4 \pm 0.04$ \\
\hline \multirow{2}{*}{$10 \mathrm{sec}$} & $\mathrm{Rmax}$ & $3.0 \pm 0.08$ & $2.4 \pm 0.04$ \\
\hline & $\mathrm{Ra}$ & $0.4 \pm 0.02$ & $0.3 \pm 0.06$ \\
\hline \multirow{2}{*}{$20 \mathrm{sec}$} & $\mathrm{Rmax}$ & $2.8 \pm 0.05$ & $2.0 \pm 0.14$ \\
\hline & $\mathrm{Ra}$ & $0.4 \pm 0.03$ & $0.3 \pm 0.03$ \\
\hline & & & $\begin{array}{r}\text { Mean } \pm \mathrm{SD} \\
\mathrm{n}=5 \\
\text { unit }=\mu \mathrm{m}\end{array}$ \\
\hline
\end{tabular}

粗さは小さかった。

\section{考察}

スケーリング, ルートプレーニングは, 露出セメント 質の除去や, プラークの再付着の防止, 歯石の再沈着の 抑制という意味で, 歯周治療において重要な位置を占め ている。しかしながら，露出セメント質の除去や根面の 滑沢化を得ることは難しく O’Leary ら ${ }^{8)}$ は, キュレット 型スケーラーによる 50 回のストロークによる滑沢化に よっても，全てのセメント質は除去されなかったと述べ ている。そこで著者らは, 最近, 外来性沈着物の除去に 使用されている air-powder abrasive system を応用す 
る歯面研磨装置に着目し，これをスケーリング後の歯面 研磨に応用した場合，ルートプレーニング面あるいはぺ ーストによる研磨面のような面が得られるかどうか検討 を試みた。

この歯面研磨装置の, 外来性沈着物の除去効果につい ては, すでに多くの報告があり ${ }^{1 \sim 7)}$, ラバーカップ, ペー ス卜研磨などにくらべ，短時間の操作で高い除去効果が 得られるとされている。しかしながら，同時に本装置に よる歯面損傷についても示唆されており, Atkinson ら は, 根面に 30 秒噴射した場合, 平均 $636.6 \mu \mathrm{m}$ の歯質 の損傷があったと報告している。著者らは，歯面損傷を 最小にし，かつ効率的な処置法を検討するために，噴射 時間を 3 秒， 5 秒, 10 秒および 20 秒と設定し，噴射角度 を 60 度および 90 度と定め, 歯冠寄り $1 / 3$ の歯面および 歯根中央部への効果を検討した。

その結果, SEM 観察においては, 噴射時間が長くなる にしたがい，象牙細管が鮮明に認められる像が観察され た。すなわち， 60 度噴射の 3 秒処理では，歯冠寄りおよ び歯根中央部とも歯面はかなり粗造な面を呈し, 表面の 凹凸が顕著に認められ，七メント質がかなり残留してい ると思われた。 5 秒処理では， 3 秒処理にくらべ，表面 の凹凸は小さくなるが, 10 秒処理と比較するとその凹凹 は大きく, 特に中央部ではその差が大きかった。10 秒処 理では, 表面がかなり平滑になり, 条痕は認められず象 牙細管様の像が観察できるようになった。これは，残留 セメント質がかなり除去され，象牙質面が現れてきた像 を示すものだと思われる。20秒処理では, 10 秒処理と比 較して顕著な差は認められなかった。10秒処理で, 残留 セメント質の多くが除去されるのではないかと推測され る。90 度噴射面では， 3 秒間で 5 秒間 60 度噴射処理面 に近い所見が，歯冠寄り，中央部ともに観察された。歯 根の歯冠寄りと中央部を比較すると, 明らかに歯冠寄り の処理面の方が, 短時間で凹凹が小さく平滑な像が認め られた。通常, セメント質は, エナメルーセメント境で もっとも薄く $(20 \sim 50 \mu \mathrm{m})$, 根尖の方に向かって最も厚 くなる $(150 \sim 200 \mu \mathrm{m})$ といわれており, 本結果は, セメ ント質の厚さの影響だと考えられ，歯冠寄りと根尖寄り とでは噴射時間を変える必要があることが示唆された。

噴射角度の比較では， 3 秒， 5 秒処理ともに，60 度処 理面では，歯冠側から歯根側へ向けてのめくれあがりが 認められ，90 度処理面では，表面の凹凸が小さい像が観 察された。これらの像は, 噴射による影響だと思われる が, 90 度処理面の方が 60 度処理面よりも凹凸が小さく 平滑であった。10 秒, 20 秒処理面では, 60 度処理面のめ
くれあがりおよび 90 度処理面の小さな凹凸はほとんど 消失し, 両者の差はほとんど認められなくなった。これ らのことから, 角度としては 90 度の方がよいように思 われた。

表面粗さについては, 噴射時間が長くなるにしたがい, 表面粗さが小さくなるという結果を得たが, 10 秒処理と 20 秒処理では有意な差は認められなかった。この結果 は, SEM 観察における噴射時間と平滑さの関係に一致 するものである。

一方, 60 度処理面と 90 度処理面をくらべた場合, 各時 間ともに, 90 度処理面の方が, 60 度処理面にくらべて粗 さが小さいという結果を得た。この結果も, SEM 観察に おける所見に一致するように思われた。

本実験で得られた表面粗さを, スケーリング後, ラバ 一カップ, 浮石末にて 20 秒間研磨した郷家ら ${ }^{3)}$ の報告 による歯面の粗さと比較してみると, ラバーカップ後の 歯面の最大粗さ $\left(R_{\max }\right)$ は $3.40 \mu \mathrm{m}$, 標準粗さ $(\mathrm{Ra})$ は $0.55 \mu \mathrm{m}$ であり, 著者らの, 5 秒間, 90 度の噴射処理面 $\left(\mathrm{R}_{\max }=3.1 \pm 0.13 \mu \mathrm{m}, \mathrm{Ra}=0.4 \pm 0.04 \mu \mathrm{m}\right)$ および 10 秒, 60 度の噴射処理面 $(\mathrm{R} \max =3.0 \pm 0.08 \mu \mathrm{m}, \mathrm{Ra}=$ $0.4 \pm 0.02 \mu \mathrm{m})$ とほぼ同様の值であった。

このような結果から, 使用部位における噴射時間, 噴 射角度を考慮して用いるならば，本装置はスケーリング 後のルートプレーニング的な役割を果たすと考える。

\section{結論}

著者らは，歯面研磨装置を用いてスケーリング後の歯 面に 3 秒， 5 秒， 10 秒および 20 秒と, チップの角度を 60 度および 90 度と変え噴射し，その影響を SEM によ り観察し, 併せて各表面粗さを測定し, 以下の結論を得 た。

1. 歯冠寄りの 60 度, 90 度処理面では， 3 秒処理に おいてはスケーリング時の条痕や 60 度処理面のめくれ あがり，90 度処理面の小凹凸が認められ粗造であった が， 5 秒以上の処理面では条痕や, 表面の凹凸が不鮮明 になり，象牙細管様構造も認められた。

2. 中央部の 60 度, 90 度処理面では, 3 秒, 5 秒処 理においてスケーリング時の条痕や, 60 度処理面のめく れあがり, 90 度処理面の小凹凹が認められたが, 10 秒以 上の処理面ではそれらが不鮮明となり, 象牙細管様構造 も認められた。

3. 表面粗さは, 噴射時間が長くなるにしたがい小さ くなった。また，90 度処理面は，60 度処理面にくらべ， 
表面粗さは小さかった。

\section{文献}

1) Weaks, L.M., Lescher, N.B., Barnes, C.M. and Holroyd, S.V. : Clinical evaluation of the Prophy-jet as an instrument for routine removal of tooth stain and plaque. J. Periodontol., 55 : 486-488, 1984.

2）永目誠吾, 中井孝佳, 竜門睦正, 森 孝, 上村参 生, 白石雅照, 小西浩二 : Prophy-jet に上る歯 面沈着物の除去勃果. 歯界 展 望, $63: 541-548$, 1984.

3）郷家英二, 田中憲二, 村井正大 : 歯面研磨装置に ついてークイック・ジェットの使用例と表面粗さ の評価一. 紫耀, $38:$ 583-593, 1985.

4) 久保田稔, 遠藤 修, 安藤良彦, 佐藤 保, 中嶋 和郎, 菊池由紀子, 熊谷敦史 : 歯面研磨器の歯質 および修復材におよぼす影響一表面性状の変化に 関寸る基礎的研究一. 日歯保 誌, $28: 681-689$,
1985.

5）上田雅俊, 稲田芳樹, 高津兆雄, 吉田誠規, 山岡 昭, 岩井広茂, 中村喜昭, 楠 憲治, 小西浩二 : 歯面沈着物の除去に関する研究 (第 1 報). 日歯周 誌, $27: 588-595,1985$.

6）上田雅俊，稲田芳樹，高津兆雄，沢田好章，山岡 昭, 加藤成樹, 加藤直樹, 楠 憲治, 小西浩二: 歯面着色物の除去に関する研究 (第 2 報). 日歯周 誌, $28: 340-346,1986$.

7）河村英世 : 歯面研磨装置クイックジェットに関す る研究一特に噴射時間が歯根面におよぼす形態学 的影響について一. 日大歯学, $61: 296-301,1987$.

8) O'Leary, T.J. and Kafrawy, A.H. : Total cementum removal ; A realistic objectives ?. J. Periodontol., 54 : 221-226, 1983.

9) Atkinson, D.R., Cobb, C.M. and Ki loy, W.J. : The effect of an air-powder abrasive system on in vitro root surfaces. J. Periodontol ., 55 : 13-18, 1984. 